\title{
Insurance companies fight for rights to genetic data
}

London. Representatives of Europe's leading insurance companies are meeting in Paris this week to discuss how they can head off legislation aimed at restricting their access to genetic information about those seeking insurance cover.

The meeting is a response to growing concern that such information could be used to discriminate against individuals whose genome reveals a susceptibility to particular diseases, particularly if this information falls into the hands of employers.

Denmark has already debated legislation making it illegal for genetic information to be passed to insurance companies or employers. Parliamentary groups in several other European countries - including the United Kingdom - are also discussing whether to make similar moves.

Further action is taking place at the European level. An amendment is being proposed to a report being voted on later this month by the energy and technology committee of the European Parliament which urges legislation prohibiting doctors and medical authorities from disclosing genetic information about a patient.

Insurance companies have already expressed their opposition to any such moves. They argue that, at least in cases where genetic information is obtained as part of a medical assessment, it should be treated like any other medical information. Not revealing such information, they claim, could invalidate an insurance contract - and would also be unfair on those with a clean genetic bill of health.

At present, the information available through genetic tests is unlikely to make a significant difference to the approach already taken by insurance companies. The main concern is over the use that insurance companies are likely to be tempted to make of genetic information in the future, particularly because the more sophisticated this information becomes, the more directly it will be possible to assess the health prospects of individuals

Officials of the Association of British Insurers (ABI) point out that their members have no

\section{Polish science}

A recent article (see Nature, 364, 748; 1993) gave the incorrect figure for this year's Polish research budget. The correct figure is 9,000 billion zloty, or roughly $\$ 500$ million. Also, the state committee for scientific research has 12 (not 14) members elected by the scientific community; the chairman and secretary of the committee are appointed separately. intention of requiring genetic tests on individuals seeking insurance "within the foreseeable future". At the same time, however, they acknowledge that circumstances could change as testing becomes more accurate in its predictions, and more widely available.

"We cannot say that we will never ask someone to take a genetic test" says John Wagstaff, secretary of the ABI's medical affairs committee. "We just do not know about the future."

Some argue that, even though this prospect remains a number of years away, discussions should already be taking place between the insurance industry, genetic experts and consumer interest organizations to try to reach agreement on how to regulate the use of genetic information.

"There is a window of opportunity open at the moment; but, given the different - and sometimes opposing - interests between the different groups involved, it is not going to stay open for very long," says Peter Harper, of the Institute of Medical Genetics at the University of Wales College of Medicine in Cardiff.

But the insurance industry is nervous of the external controls to which this approach could lead. At present it is insisting that selfregulation should be sufficient. With this in mind, the $\mathrm{ABI}$, for example, is in the process of drawing up a code of practice for its members on the use of genetic information.

A similar approach is likely to emerge this week from a meeting of the members of the European Insurance Committee, a trade body based in Paris. Franz Josef Werle, the deputy secretary general of the committee, says that companies are likely to prepare a joint position paper setting out their opposition to restrictive legislation before the end of the year.

But the limits of self-regulation are also coming under increasing scrutiny. The need for mutually acceptable guidelines on how the insurance industry should proceed, for example, is expected to be emphasized by a working party of Nuffield Council on Bioethics which is due to publish a report on genetic screening within the next few months.

In the United States, an ethics subcommittee of the human genome project has proposed that the insurance industry should adopt a temporary moratorium on demanding access to the results of genetic tests until further discussion is held on how this access should be regulated.

So far, however, the industry has not warmed to this proposal. Nor have similar calls yet been made in Europe. But every announcement of a new genetic discovery is strengthening the case for government intervention to ensure that rights are protected on all sides.

David Dickson

\section{US blows cool on the prospects of rejoining UNESCO}

Washington. Officials in the Clinton administration have been dampening down hopes raised by the recommendation of a State Department task force that the United States should rejoin the United National Educational, Scientific and Cultural Organization (UNESCO) in 1995.

The task force, chaired by assistant secretary of state Douglas Bennet, opposed immediate re-entry. This had been sought by many scientific and teaching organizations in the hope that such a decision could be taken before UNESCO's general conference in Paris next month.

According to the Bennet committee, the $\$ 65$ million annual cost of such a step would make it necessary to divert funds from other programmes, which the administration is not willing to accept. But the task force did keep a window open by recommending reentry in 1995, when the United States will in theory have finished paying off its arrears to the United Nations.

Even the prospects of this happening, however, are doubtful. Officials in Washington point out that spiralling UN expenditure, for example on peace-keeping missions in countries such as Bosnia and Somalia, makes it unlikely that the arrears will be paid off, while much scepticism about UNESCO's effectiveness remains. "A goahead from on high would be sufficient, but there is no sign yet that the administration regards re-entry as a priority," says one congressional official.

Both the United States and Britain withdrew from UNESCO in 1984, complaining of management failures and excessive politicization of its programmes. Optimists at UNESCO are still hoping that, in the light of reforms carried out since then by the new director general, Federico Mayor, Clinton will announce a date for re-entry in his first address to the general assembly of the United Nations on 27 September.

Their hopes are shared by the organization's supporters in Britain, where the Foreign Affairs Committee of the House of Commons recently issued a report urging the government to rejoin, and claiming that previous objections to the activities of UNESCO have been overcome. "The debate about UNESCO's policy, budgetary and management problems has been settled, broadly in the organization's favour", the report says.

But the general view is that President Clinton will still hold back. And if a newly elected administration committed to building bridges with the UN does not champion UNESCO now, officials in Washington say it is unlikely to find the money in two years time either. 